\title{
Data report: diatom and foraminiferal assemblages in Pleistocene turbidite sediments from the Cascadia margin (IODP Expedition 311), northeast Pacific'
}

\author{
Fumio Akiba, ${ }^{2}$ Yoko Inoue, ${ }^{3}$ Megumi Saito-Kato, ${ }^{4}$ and John Pohlman ${ }^{5}$
}

\section{Chapter contents}

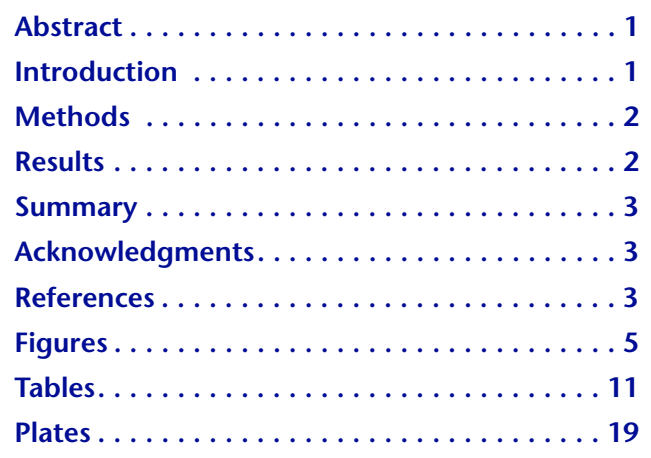

${ }^{1}$ Akiba, F., Inoue, Y., Saito-Kato, M., and Pohlman, J., 2009. Data report: diatom and foraminiferal assemblages in Pleistocene turbidite sediments from the Cascadia margin (IODP Expedition 311), northeast Pacific. In Riedel, M., Collett, T.S., Malone, M.J., and the Expedition 311 Scientists, Proc. IODP, 311: Washington, DC (Integrated Ocean Drilling Program Management International, Inc.).

doi:10.2204/iodp.proc.311.211.2009

2Diatom Minilab Akiba, Ltd., 632-12 Iwasawa, Hanno, Saitama 357-0023, Japan.

Correspondence author: Akiba357@hanno.jp

${ }^{3}$ Inoue Paleolab, 4-6-6 Hamadayama, Suginami, Tokyo 168-0065, Japan.

${ }^{4}$ National Museum of Nature and Science, 3-23-1 Hyakunin-cho, Shinjuku, Tokyo 169-0073, Japan. ${ }^{5}$ U.S. Geological Survey, Woods Hole Science Center, 384 Woods Hole Road, Woods Hole MA 02543, USA.

\section{Abstract}

Diatom and foraminiferal analyses of the Pleistocene turbidites in the Cascadia margin suggest that turbidite sediments originated mainly in the landward shelf area and were displaced to the present deep-sea site, which maintained a constant depth during this time. Abundant and highly fluctuating occurrences of shallowmarine and nonmarine diatoms may reflect the global glacioeustatic sea level changes in the Pleistocene.

\section{Introduction}

Among the major microfossil groups routinely used for biostratigraphy in deep-sea drilling projects, diatoms have the most diverse ecology occupying open-marine to terrestrial nonmarine environments. Therefore, diatoms can be used to determine the extent of any terrestrial inputs to ocean sites. Shipboard diatom analysis of turbidite sediments collected from Sites U1325-U1329 during Integrated Ocean Drilling Program Expedition 311 at the continental slope in the Cascadia margin, an accretionary complex, revealed unexpectedly abundant and highly fluctuating occurrences of shallow-marine and nonmarine diatoms for the first time (see the "Expedition 311 summary" chapter). This suggests that the turbidites originated from shelf and inland water areas andat the fluctuations may be related to the global glacioeustatic sea level changes in the Pleistocene. Previously no reports of such abundant occurrences of these diatoms have been documented, although many holes were drilled in the region during Deep Sea Drilling Project Leg 18 and Ocean Drilling Program Legs 146, 168, and 204. Schrader (1973) noted the abundant occurrences of allochthonous diatoms at Leg 18 Site 174 in the Astoria Fan, but he did not distinguish between shallow-marine and nonmarine diatoms. Fourtanier (1995) analyzed the diatoms from Leg 146 Site 892, from which no nonmarine diatoms were recorded. More recently Watanabe (2006) reported diatoms from Leg 204 sites, where only very scarce and sporadic occurrences of nonmarine diatoms were recognized.

In addition to shipboard diatom analysis, we carried out shorebased diatom and foraminifer analyses in Holes U1328B and U1328C in order to clarify their depositional environment and/or mechanism in more detail, which might be important to characterize the organic materials in the sediments generating hydrocarbons and/or gas hydrate. 


\section{Methods}

For diatom analyses, 189 samples from Sites U1325U1329 were analyzed during the expedition, and 134 samples from Holes U1328B and U1328C were examined after the expedition. About $0.5 \mathrm{~g}$ of each wet sample was processed, and the methods of sample preparation, counting, and other procedures basically followed those of Akiba (1986) with a minor modification. Diatom abundance is expressed as an approximate number of diatom valves per slide (18 $\mathrm{mm} \times 18 \mathrm{~mm}$ coverslip) calculated using the length of scanning lines needed to count 100 diatom valves. Resting spores of shallow-marine diatom genus Chaetoceros, which have generally been ignored in diatom analysis, were counted separately during the count of usual diatoms. In diatom biostratigraphic assignments, the Neogene diatom zonation and code numbers of the North Pacific Diatom Zone (NPD) by Akiba (1986) and Yanagisawa and Akiba (1998) were used. Ages for bioevents that define zones or characterize certain horizons are based on Yanagisawa and Akiba (1998). Specific occurrences of shipboard diatom analyses can be found in the site chapters, and only the occurrence of diatoms in Holes U1328B and $\mathrm{U} 1328 \mathrm{C}$ is tabulated in this report.

For foraminifer analyses, 34 core catcher samples from Holes U1328B and U1328C were examined. The amount of material examined was $10 \mathrm{~g}$ for each sample, and the methods of preparation, counting, and other procedures followed those by Inoue (1989).

\section{Results}

Sites U1325 (2195 m water depth), U1326 (1828 m water depth), U1327 (1305 $\mathrm{m}$ water depth), and U1329 (946 m water depth) were cored along a southwest-northeast transect on the continental slope, and Site U1328 (1268 m water depth) was drilled south of Site U1327. The shipboard diatom analyses of these five sites revealed that all sites contained diatom remains, though their abundances vary drastically, ranging from barren to $>10,000$ diatom valves per slide. Species compositions of diatoms also vary rather drastically (see Figs. F1, F2, and F3 in the "Expedition 311 summary" chapter). Diatom assemblages are mostly composed of shallowmarine and nonmarine species (Pls. P1, P2, P3). Nonmarine diatoms recognized in the Expedition 311 sediments are dominated by planktonics. Diatom biostratigraphic zonation showed that all sediments recovered from Sites U1325-U1328 are Pleistocene and those from Site U1329 are Pleistocene to upper Miocene. The Pleistocene zonations are repre- sented by the Neodenticula seminae (NPD12;0-0.3 $\mathrm{Ma})$, Proboscia curvirostris (NPD11; 0.3-1.0 Ma), and Actinocyclus oculatus (NPD10; 1.0-2.0 Ma) Zones. The upper Miocene zonations are represented by the Rouxia californica (NPD7A; 6.4-7.6 Ma) and Thalassionema schraderi (NPD6B; 7.6-8.5 Ma) Zones (Pls. P1, P4).

Sites U1325 and U1326, situated near the southwest end of the transect, show similar occurrences of diatoms (Fig. F1). At Site U1325 diatoms are rare to common in lithostratigraphic Units I (see the "Site U1325" chapter) and II, where Zones NPD12 and NPD11 are recognized. Unit III yields very rare diatoms, and no diatom zonal species were detected. At both sites, abundance peaks of diatoms are recognized near the core tops. At Site U1326, diatoms are rare to common in lithostratigraphic Unit I and the upper part of Unit III, where Zones NPD12 and NPD11 are recognized. The two zones are separated by a barren interval of Unit II. The lower part of Unit III contains very rare to no diatoms.

Sites U1327 and U1328, both located midslope of the accretionary prism, show similar patterns of diatom occurrences (Fig. F2). Abundances of overall diatoms and resting spores of Chaetoceros spp. fluctuate, with common to very abundant occurrences in the middle part of the sections (lithostratigraphic Unit II) at both sites. The three Pleistocene diatom zones, NPD12, NPD11, and NPD10, are recognized at these sites. The zonal boundaries of the former two zones and the latter two zones are indicated by $0.3 \mathrm{Ma}$ and 1.0 Ma (Yanagisawa and Akiba, 1998), respectively. Zone NPD10 ranges from 1.0 to $2.0 \mathrm{Ma}$ (Yanagisawa and Akiba, 1998), but this zone at both sites contains $P$. curvirostris in basal samples, which restricts the age of the sites to $<1.6 \mathrm{Ma}$.

The most characteristic feature recognized at these sites is large and frequent fluctuations in the ratio of marine versus nonmarine diatoms, which varies between $0 \%$ and $100 \%$. Marine diatom assemblages are dominated by shallow-marine species, and their abundances are mostly concordant with Chaetoceros resting spores. Nonmarine diatoms assemblages are dominated by such planktonic genera as Aulacoseira and Cyclotella, which constitute $>90 \%$ of nonmarine assemblages (Table T1; Pls. P1, P2). This suggests that sediments supplied from terrestrial areas were lacustrine, not river deposits. Fluctuation patterns at the two sites appear very similar to each other. At both sites, 7-8 cycles of peaks and troughs can be recognized, and one cycle ranges from 30 to $40 \mathrm{~m}$ thick. The more closely spaced detailed diatom analysis of Site U1328 carried out in this study (Fig. F3; Table T1) revealed that the fluctuation of marine versus nonmarine diatoms is represented by very high 
frequencies several times higher than those detected by the shipboard analysis. This fluctuation pattern was compared to one of the global oxygen isotope curves (de Garidel-Thoron et al., 2005), which are generally thought to reflect the global glacial sea level changes in the Pleistocene (Fig. F4). The comparison shows that our diatom data are comparable to the oxygen isotopic curve at least in the order of cycle frequency in both data sets, especially in the interval younger than $1 \mathrm{Ma}$, although not all the peaks and troughs between the two curves are correlative, probably because most of the diatoms are displaced from landward areas as is explained next. This may imply that the fluctuation of marine versus nonmarine diatoms at Site U1328 reflects the global glacial sea level changes during the Pleistocene. Nonmarine diatoms might be easily transported to the site during the low sea level glacial stages and not during highstands of interglacial stages.

The dominant and fluctuating occurrences of shallow-marine and nonmarine diatoms at Site U1328 might indicate that the paleobathymetry of this site became significantly shallower. To test this possibility, foraminiferal assemblages from Holes U1328B and U1328C were examined (Table T2). The result shows that benthic foraminifers in the site are characterized by predominance of calcareous forms, composed mostly of such deep-sea dwellers as Bolivina spissa, Epistominella pacifica, Islandiella norcrossi, and Uvigerina curticosta with unexpectedly very few admixtures of shallow-marine species in the uppermost part of the site, indicating that the paleobathymetry of the site has been almost constantly upper middle bathyal (1500-2000 m), namely within a depth range of the present water depth at Site U1328, and became slightly shallower near the top of the site. This result is consistent with that of Zellers (1995) for Leg 146 Hole 889A, which is located between Sites U1327 and U1328. Occurrence patterns of diatoms and foraminifers look rather different from each other, suggesting that the high-productivity areas for diatoms and foraminifers were different. This difference may well be reflected by their dominance in different habitats; diatom assemblages dominated in shallow-marine and nonmarine habitats and foraminiferal assemblages were deep-sea dwellers. In conclusion, the results of diatom and foraminiferal analyses suggest that the Pleistocene turbidite sediments originated mainly from the shelf and inland water areas and were displaced to the deepwater site. We conclude this because the diatom assemblages are mainly composed of shallow-marine and nonmarine species and the benthic foraminiferal assemblages comprise those of upper middle bathyal depths. The displacement of shallow-marine and nonmarine diatoms and sediments to the present deep site might be closely related to the frequently occurring earthquakes associated with the subsidence of the Juan de Fuca plate under the North American plate.

At Site U1329, located most landward of the transect and near the edge of continental slope and shelf, diatoms are rare in lithostratigraphic Units I and III and common to very abundant in Unit II (Fig. F4). Diatom biostratigraphy reveals that Units I and II are Pleistocene, represented by Zones NPD12, NPD11, and NPD10, in descending order. The upper and middle part of Unit III is upper Miocene, represented by Zones NPD7A and NPD6B. The basal part of the unit contains no age-diagnostic diatoms, and its geologic age is unknown at present. The Pleistocene section of this site is dominated by marine diatoms, and no obvious marine/nonmarine fluctuation is recognized. The diatom zonal assignment suggests that the sediments representing $\sim 5$ m.y. are missing by either a hiatus or a fault at the boundary of Units II and III (Fig. F5).

Using the diatom biostratigraphic events recognized at the five sites (Table T3), sedimentation rate curves for them are constructed (Fig. F6). The figure demonstrates that the sedimentation rates of the Pleistocene section of these sites increase concordantly with their distance from the shelf edge.

\section{Summary}

Expedition 311 materials can provide unique information regarding the depositional environments and mechanism of turbidite sedimentation at the Cascadia margin, which may be closely related to the characterization of hydrocarbon or gas hydrate generating organic materials in the sediments, and also to the subsidence history of Juan de Fuca.

\section{Acknowledgments}

The senior author expresses his many thanks to all the scientists and crew of Expedition 311 of the JOIDES Resolution for their participation. We thank Gigi Delgado and Catherine Stickley for their careful review of the manuscript and Takashi Tsuji for his constructive discussion. This study used samples and/or data provided by the Integrated Ocean Drilling Program (IODP).

\section{References}

Akiba, F., 1986. Middle Miocene to Quaternary diatom biostratigraphy in the Nankai Trough and Japan Trench, and modified lower Miocene through Quaternary dia- 
tom zones for middle-to-high latitudes of the North Pacific. In Kagami, H., Karig, D.E., Coulbourn, W.T., et al., Init. Repts. DSDP, 87: Washington, DC (U.S. Govt. Printing Office), 393-481. doi:10.2973/ dsdp.proc.87.106.1986

Fourtanier, E., 1995. Neogene diatom biostratigraphy of Site 892, Cascadia margin. In Carson, B., Westbrook, G.K., Musgrave, R.J., and Suess, E. (Eds.), Proc. ODP, Sci. Results, 146 (Pt. 1): College Station, TX (Ocean Drilling Program), 63-77. doi:10.2973/odp.proc.sr.1461.206.1995

de Garidel-Thoron, T., Rosenthal, Y., Bassinot, F., and Beaufort, L., 2005. Stable sea surface temperatures in the western Pacific warm pool over the past 1.75 million years. Nature (London, U. K.), 433(7023):294-298. doi:10.1038/nature03189

Inoue, Y., 1989. Northwest Pacific foraminifera as paleoenvironmental indicators. Sci. Rept. Inst. Geosci., Univ. Tsukuba, Sec. B, 10:57-162.

Schrader, H.-J., 1973. Cenozoic diatoms from the northeast Pacific, Leg 18. In Kulm, L.D., von Huene, R., et al., Init. Repts. DSDP, 18: Washington, DC (U.S. Govt. Printing Office), 673-797. doi:10.2973/dsdp.proc.18.117.1973
Watanabe, M., 2006. Data report: diatom biostratigraphy of Sites 1251 and 1252. In Trehu, A.M., Bohrmann, G., Torres, M.E., and Cowell, F.S. (Eds.), Proc. ODP, Sci. Results, 204: College Station, TX (Ocean Drilling Program), 1-10. doi:10.2973/odp.proc.sr.204.123.2006

Yanagisawa, Y., and Akiba, F., 1998. Refined Neogene diatom biostratigraphy for the northwest Pacific around Japan, with an introduction of code numbers for selected diatom biohorizons. J. Geol. Soc. Jpn., 104:395414.

Zellers, S.D., 1995. Foraminiferal biofacies, paleoenvironments, and biostratigraphy of Neogene-Quaternary sediments, Cascadia margin. In Carson, B., Westbrook, G.K., Musgrave, R.J., and Suess, E. (Eds.), Proc. ODP, Sci. Results, 146 (Pt. 1): College Station, TX (Ocean Drilling Program), 79-113. doi:10.2973/odp.proc.sr.1461.208.1995

Initial Receipt: 7 August 2008

Acceptance: 4 December 2008

Publication: 18 March 2009

MS 311-211 
Figure F1. Diatom abundance, marine vs. nonmarine diatoms, and Chaetoceros resting spore abundance based on shipboard analysis data (see the "Expedition 311 summary" chapter), Sites U1325 and U1326. NPD = North Pacific Diatom Zone.

Site U1325
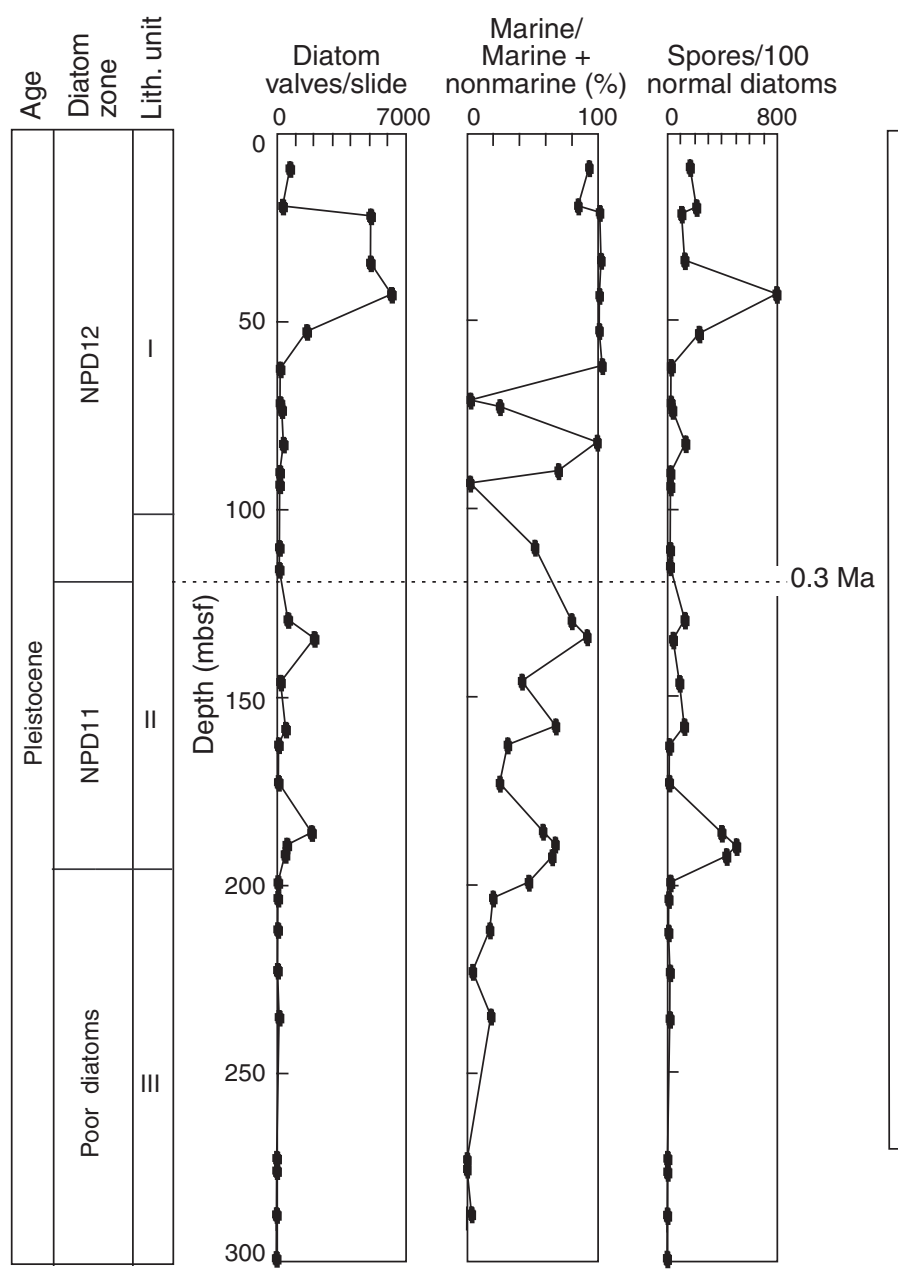

هั

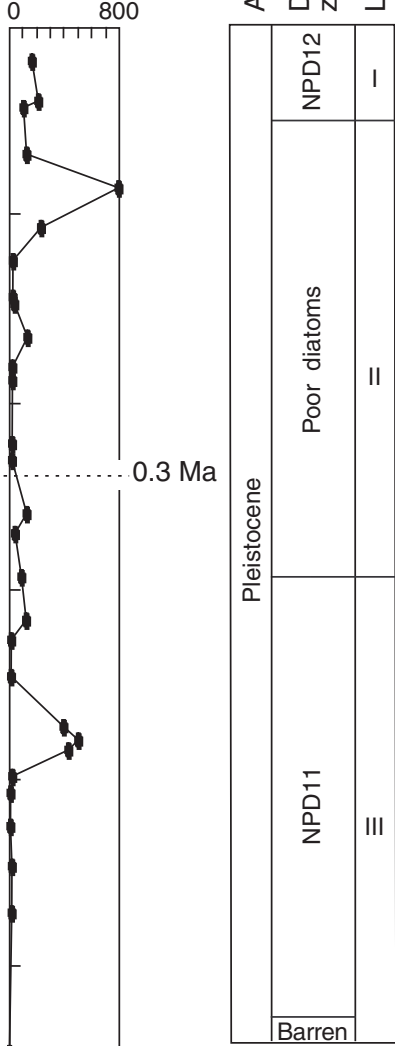

Site U1326

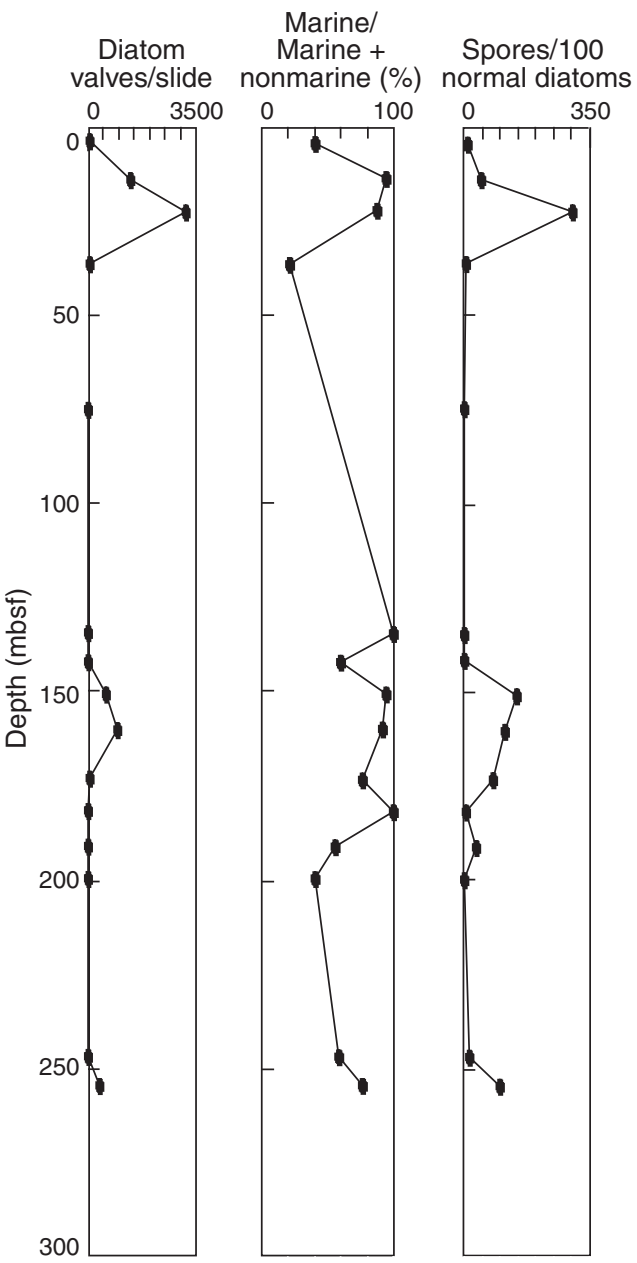


Figure F2. Diatom abundance, marine vs. nonmarine diatoms, and Chaetoceros resting spore abundance based on shipboard analysis data (see the "Expedition 311 summary" chapter), Sites U1327 and U1328. NPD = North Pacific Diatom Zone.

Site U1327

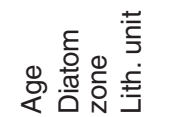

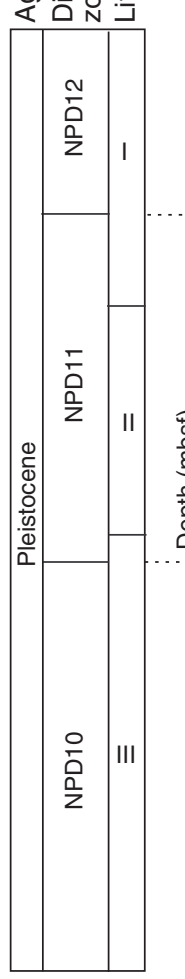

Diatom
valves/slide

$0 \quad 5000$

Marine/

Marine $+\quad$ Spores $/ 100$

nonmarine $(\%)$ normal diatoms

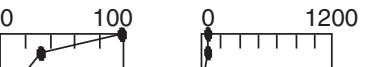

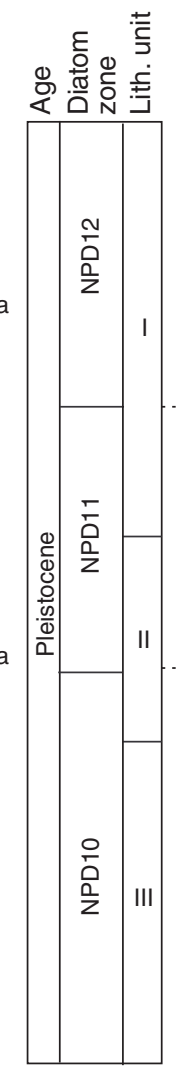

Site U1328

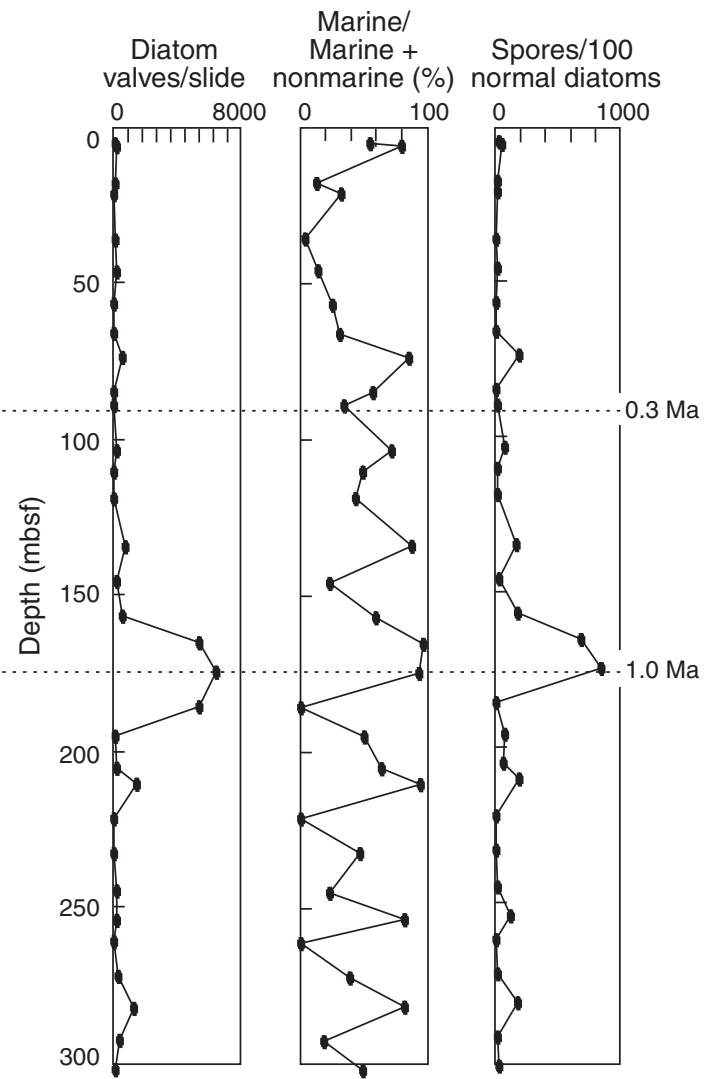


Figure F3. Diatom abundance, marine vs. nonmarine diatoms, and Chaetoceros resting spore abundance based on shore-based analysis of higher resolution sampling, Site U1328. NPD = North Pacific Diatom Zone.

Site U1328

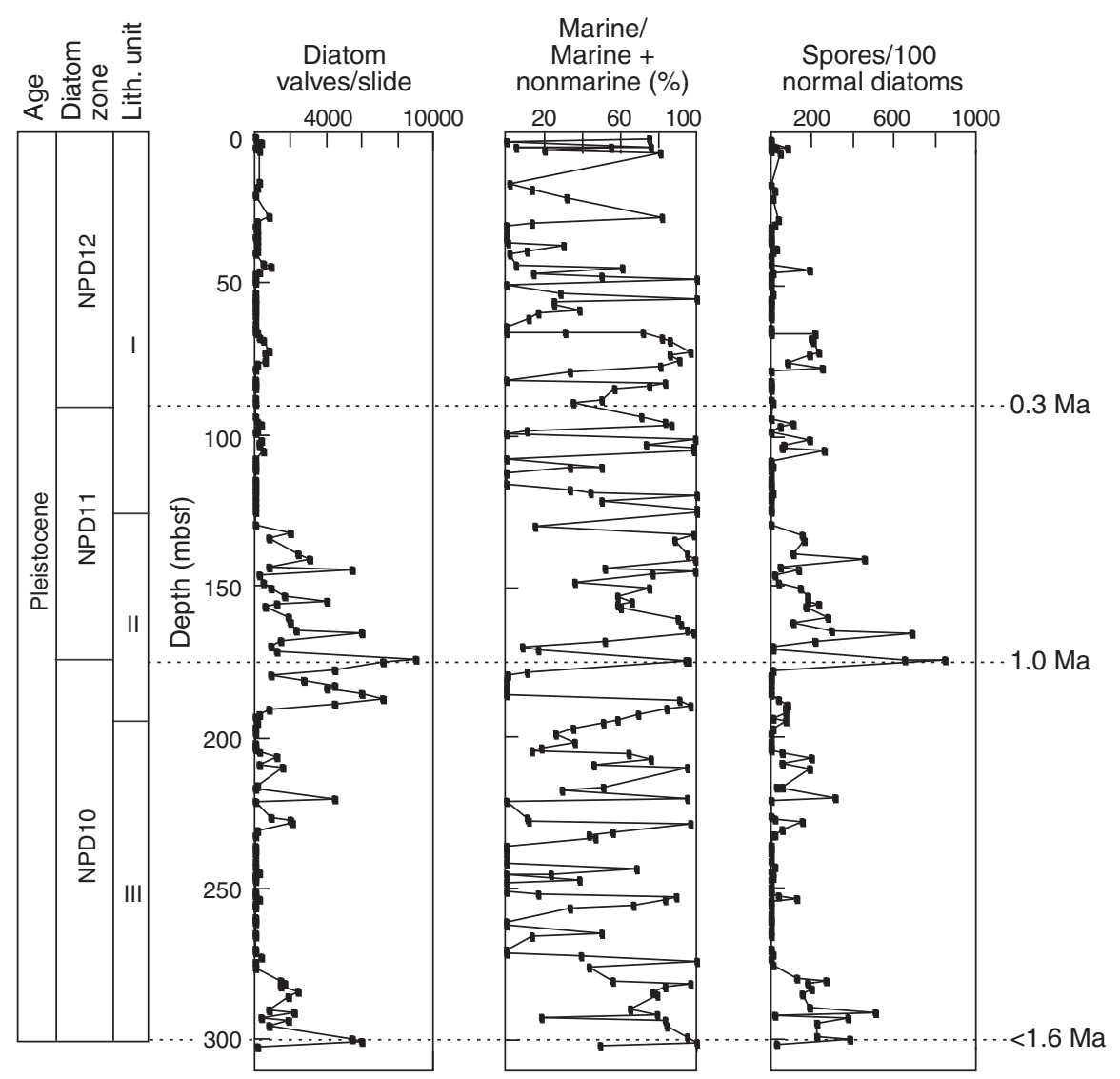


Figure F4. Comparison of marine vs. nonmarine diatom ratio at Site U1328 and global oxygen isotope curve by de Garidel-Thoron et al. (2005). NPD = North Pacific Diatom Zone.

\section{Site U1328}
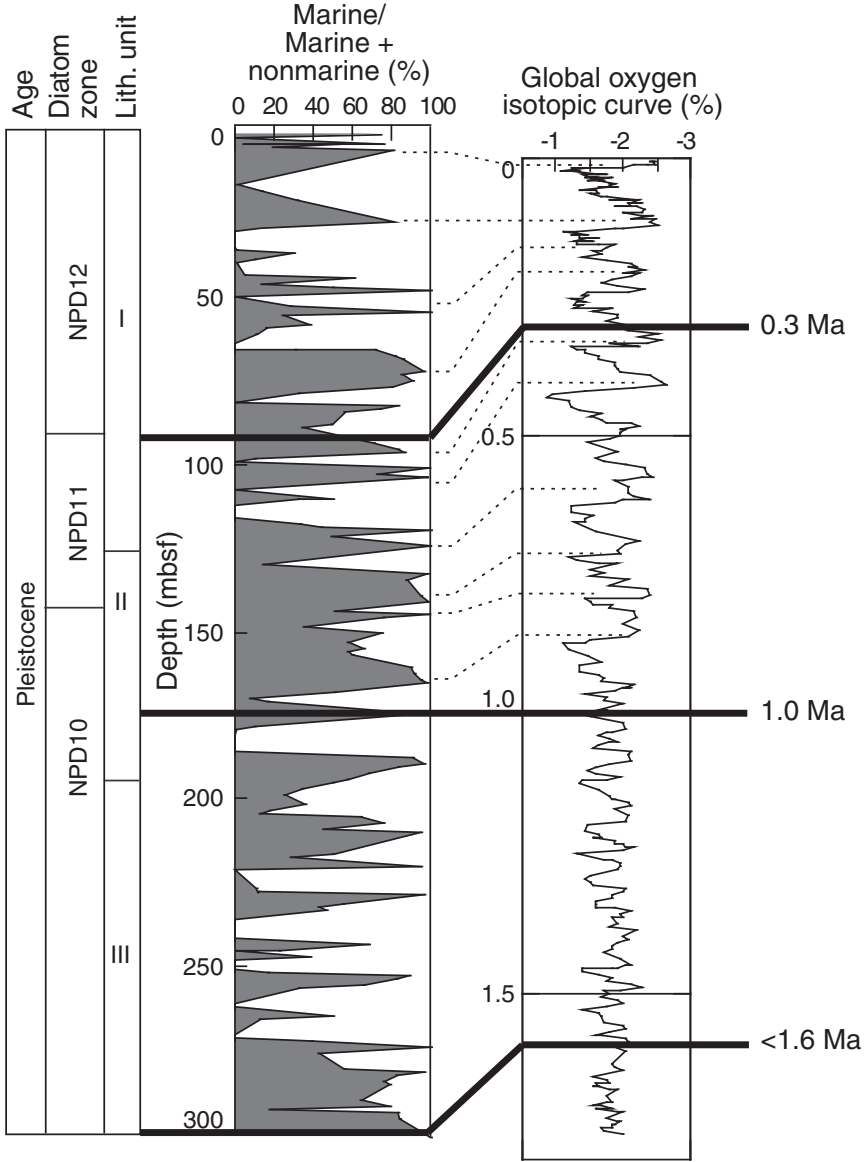
Figure F5. Diatom abundance, marine vs. nonmarine diatoms, and Chaetoceros resting spore abundance based on shipboard analysis data (see the "Expedition 311 summary" chapter), Site U1329. NPD = North Pacific Diatom Zone.

Site U1329

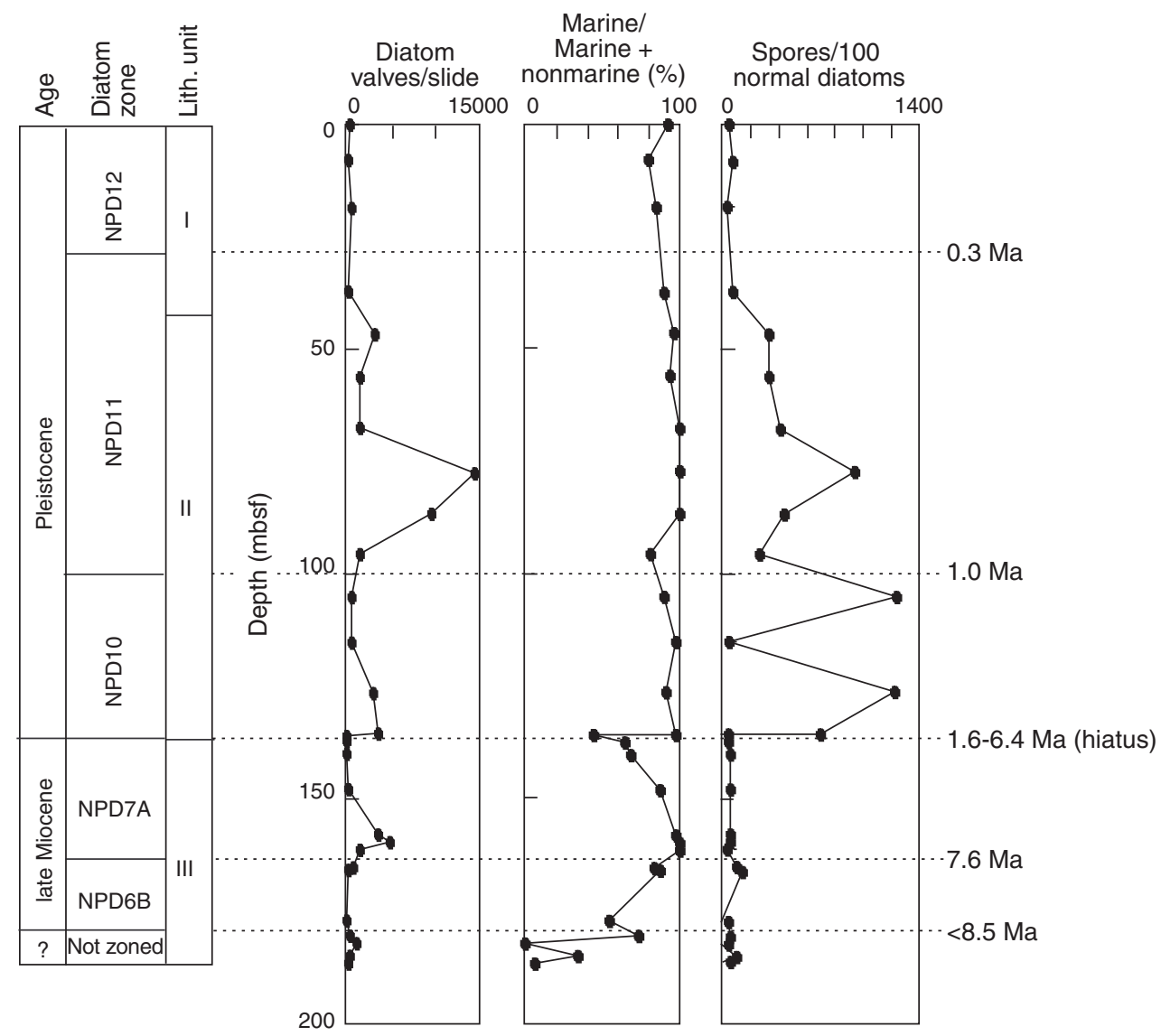


Figure F6. Depth vs. age plot for Sites U1325-U1329.

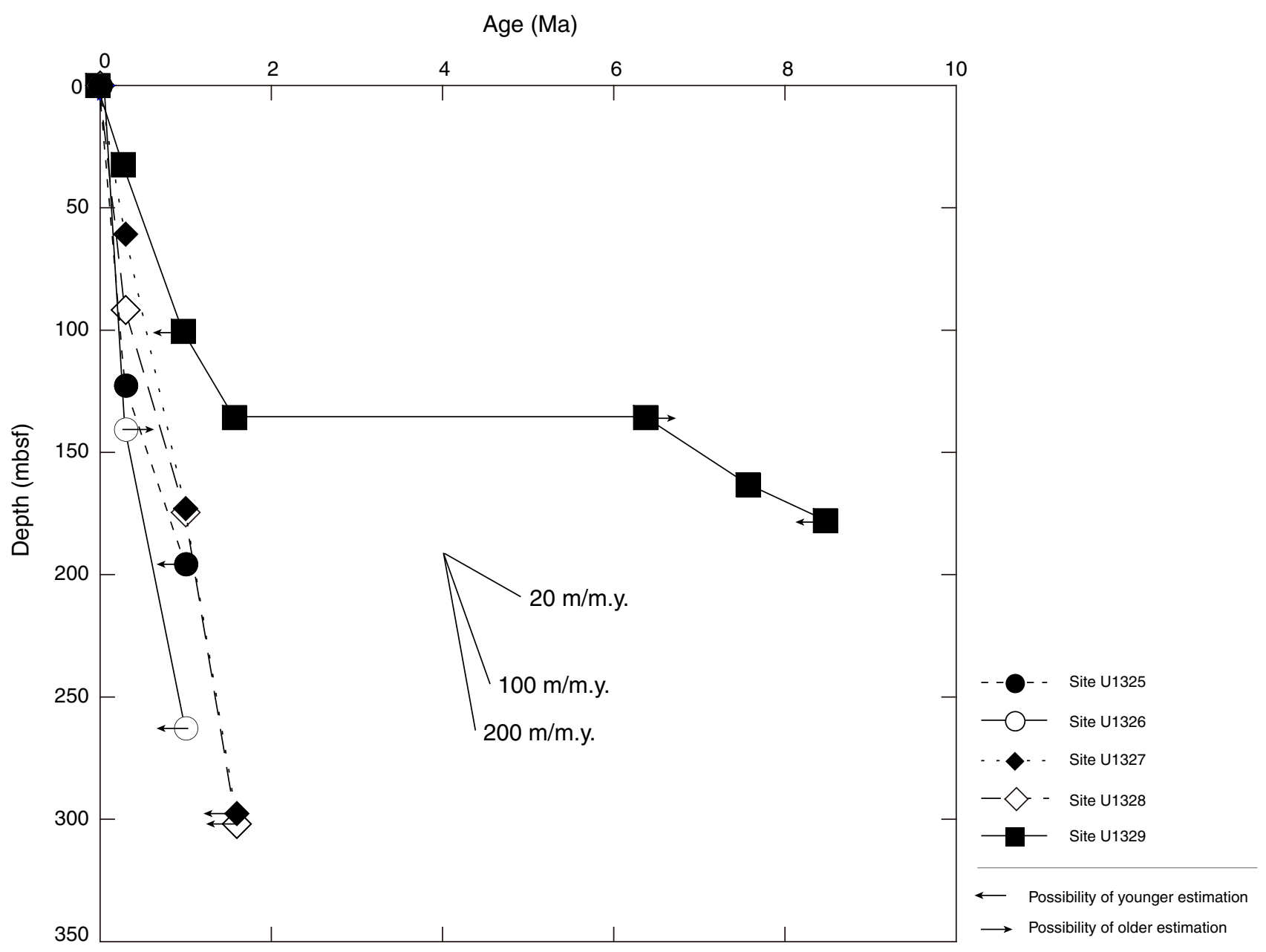


Table T1. Pleistocene diatoms, Holes U1328B and U1328C. (See table notes.) (Continued on next six pages.)

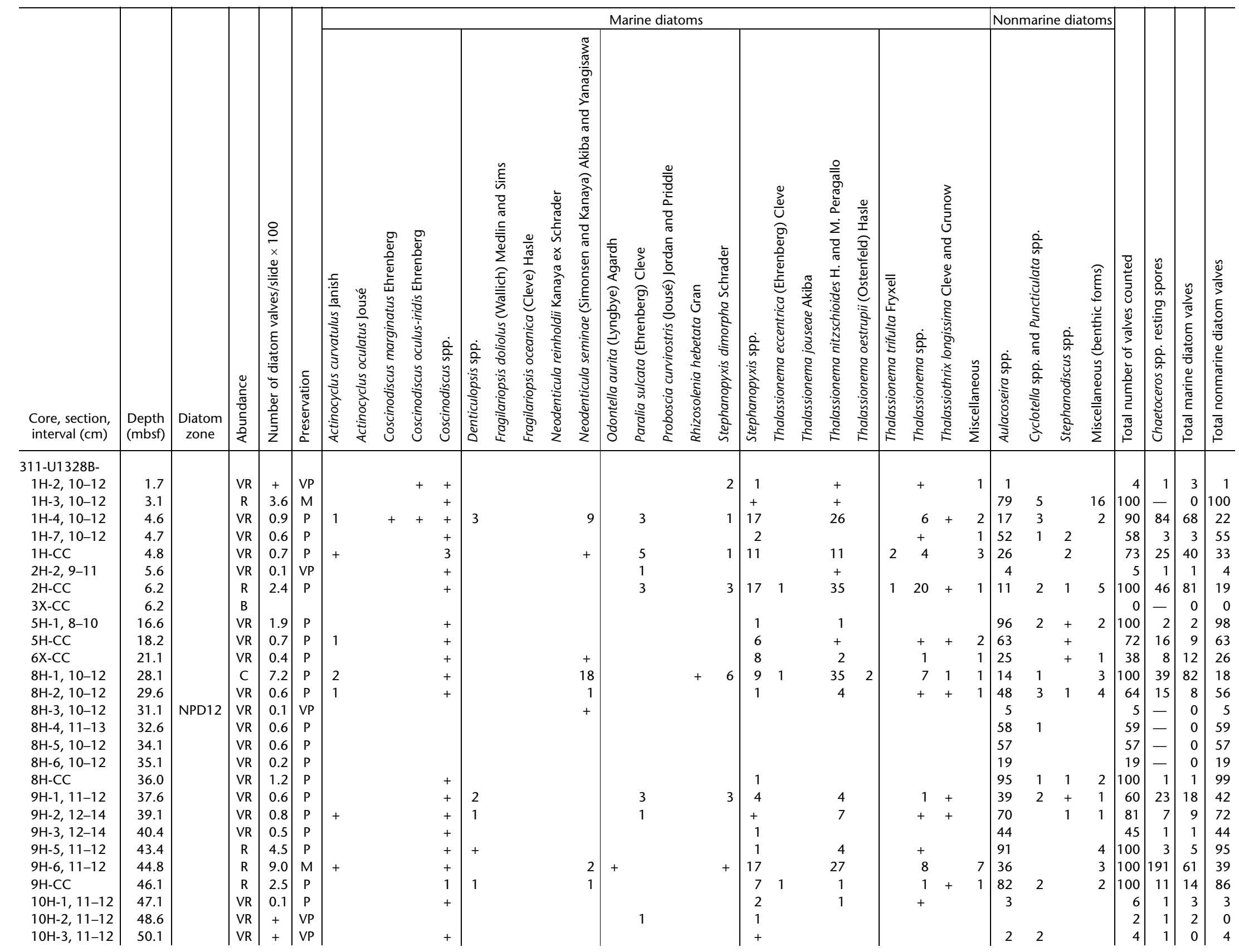




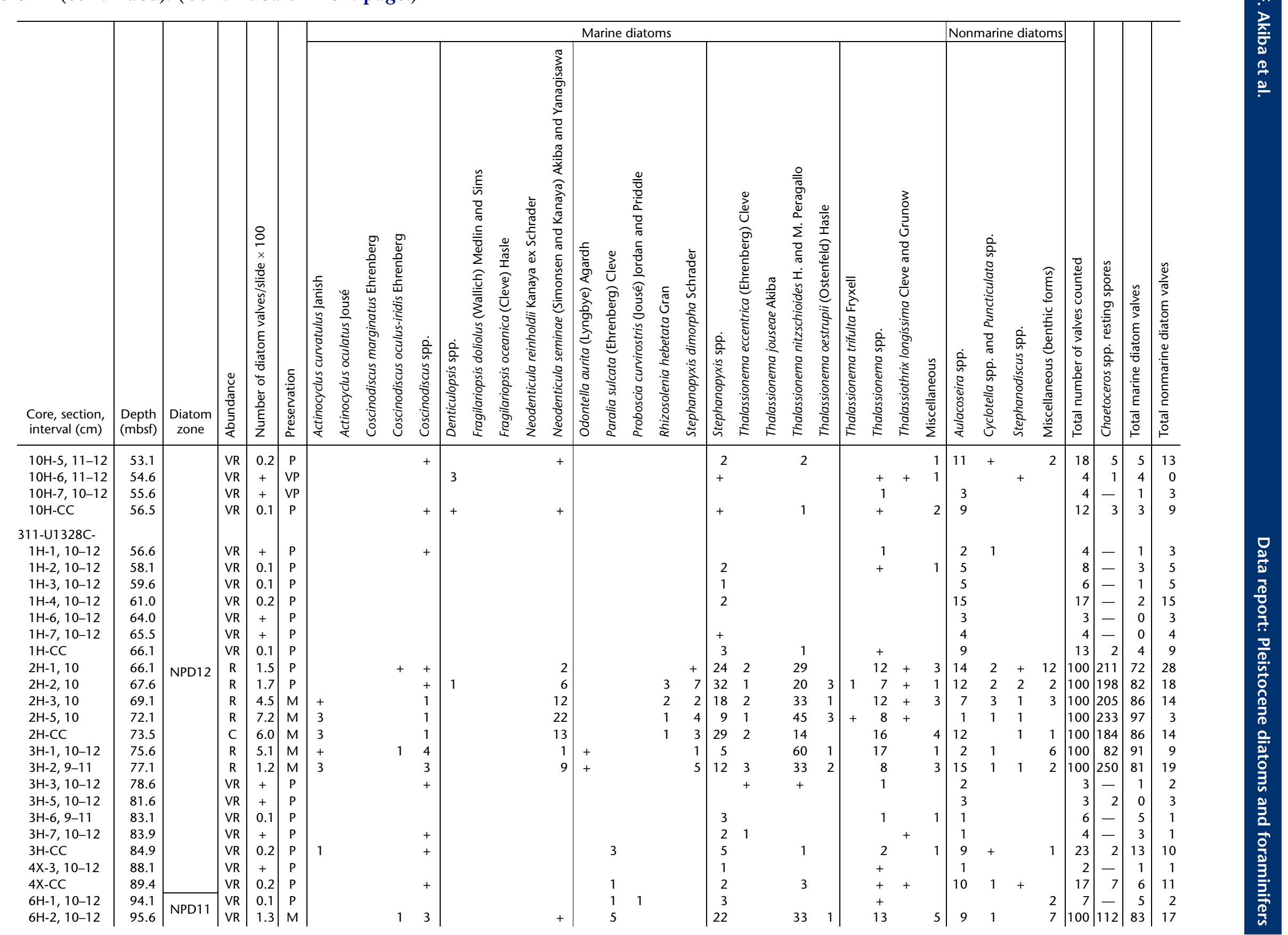




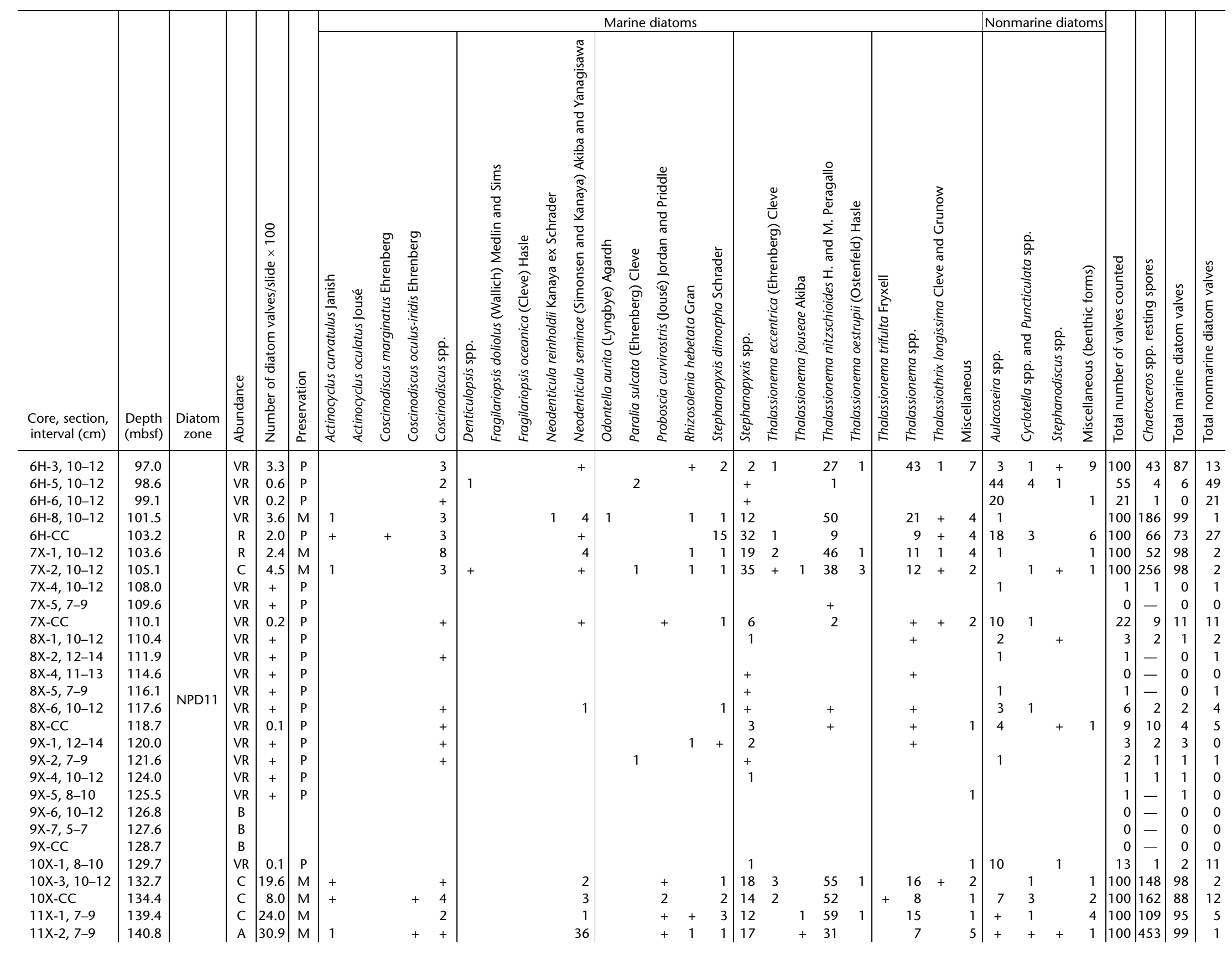




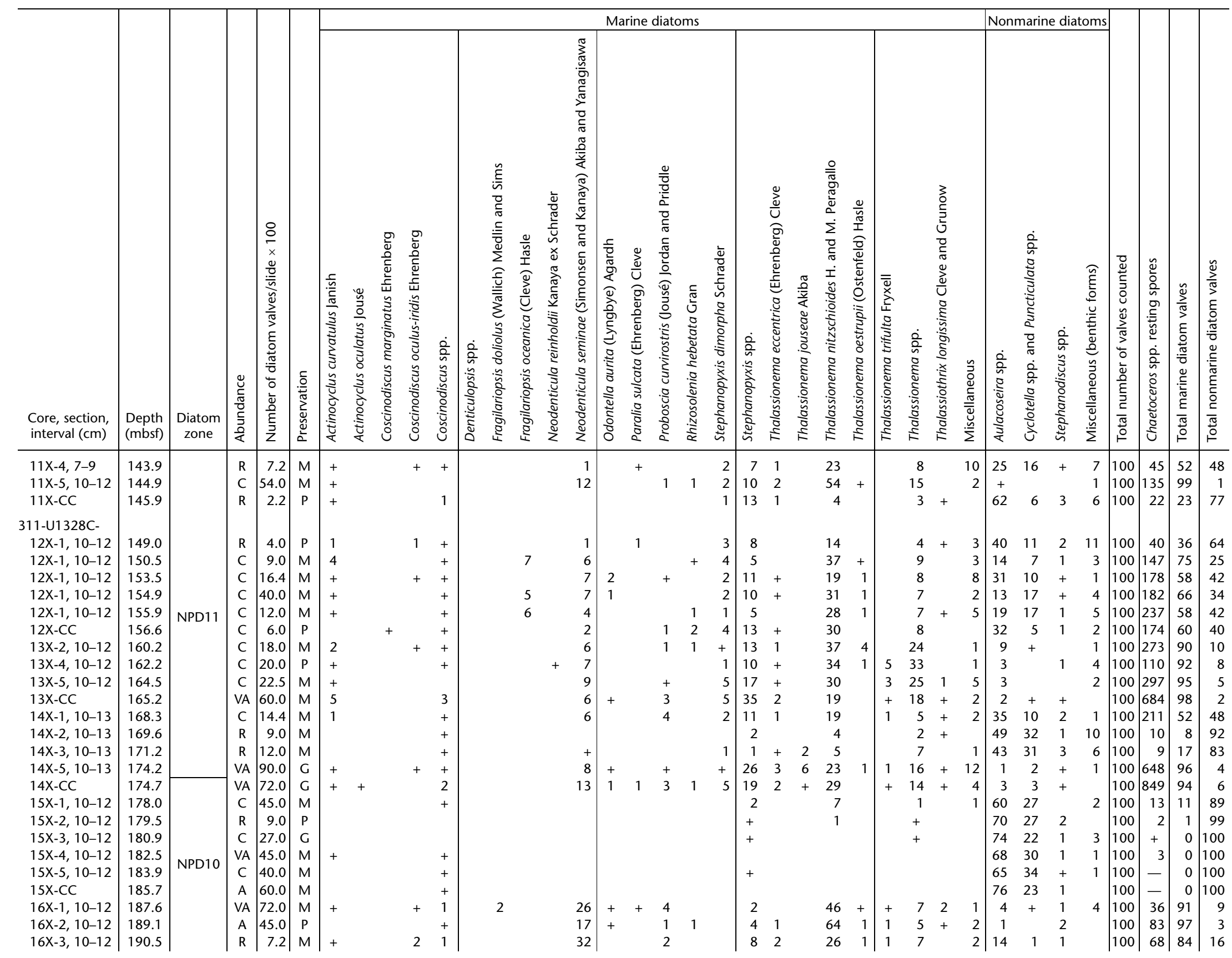




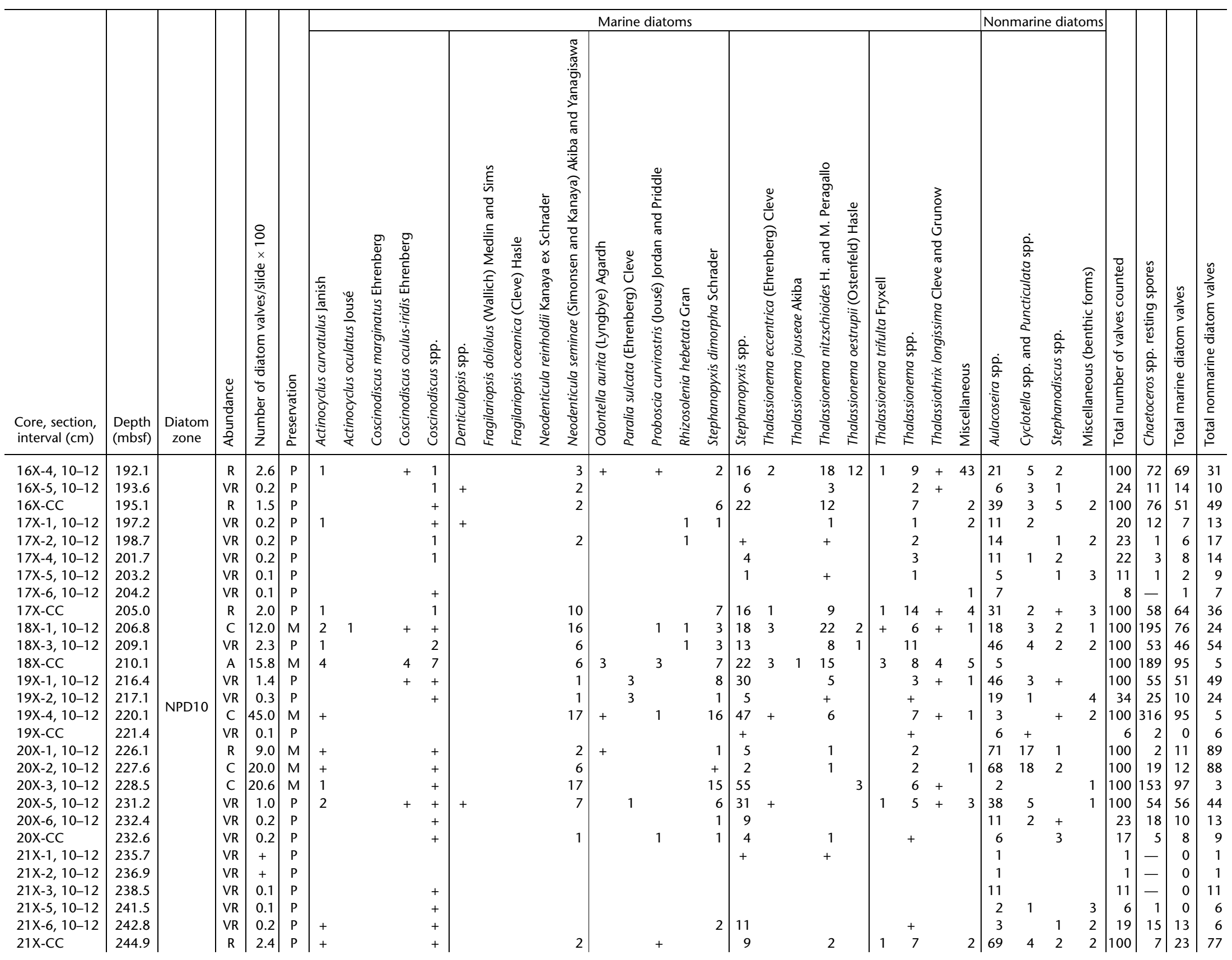




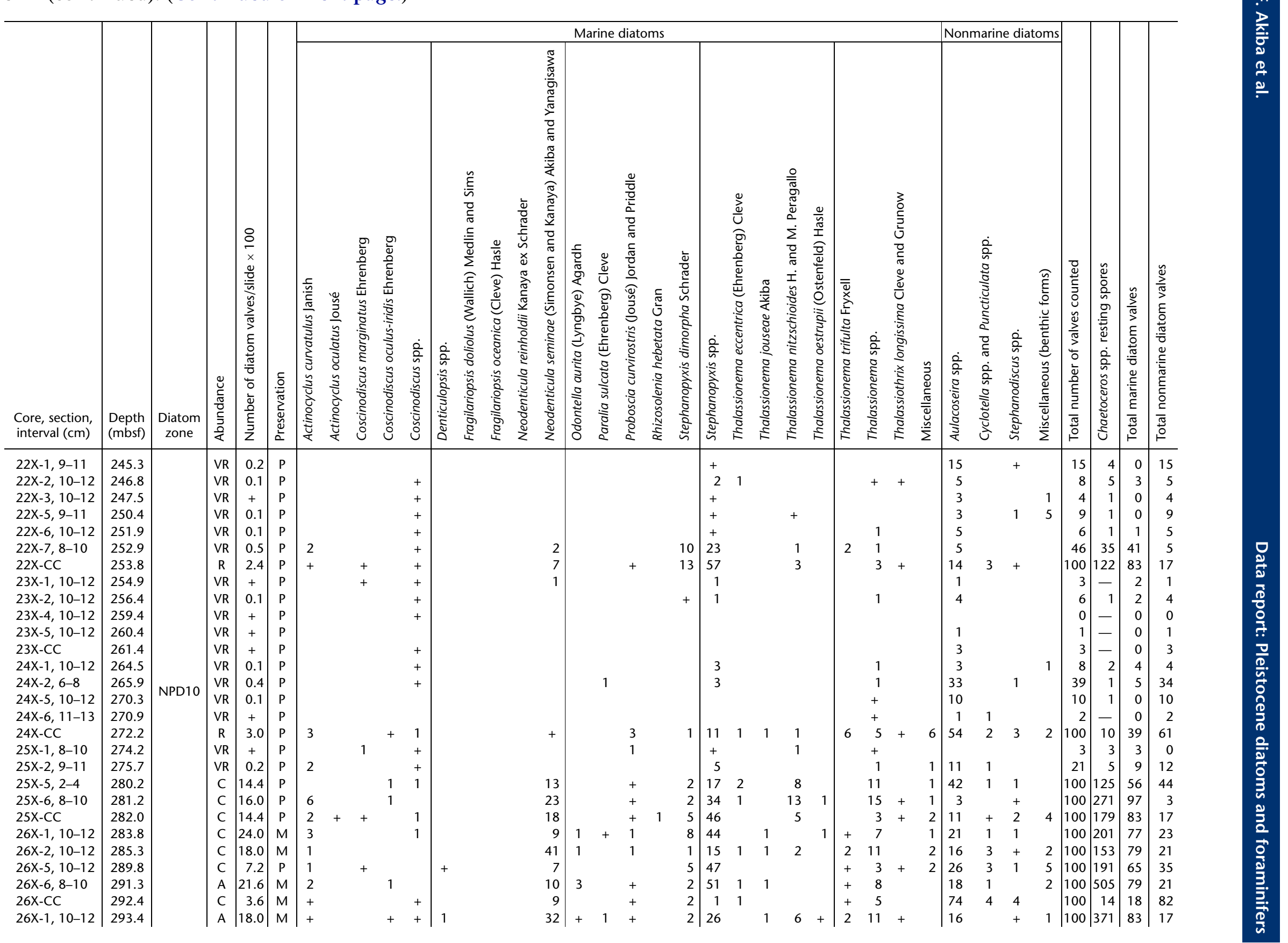


Table T1 (continued).

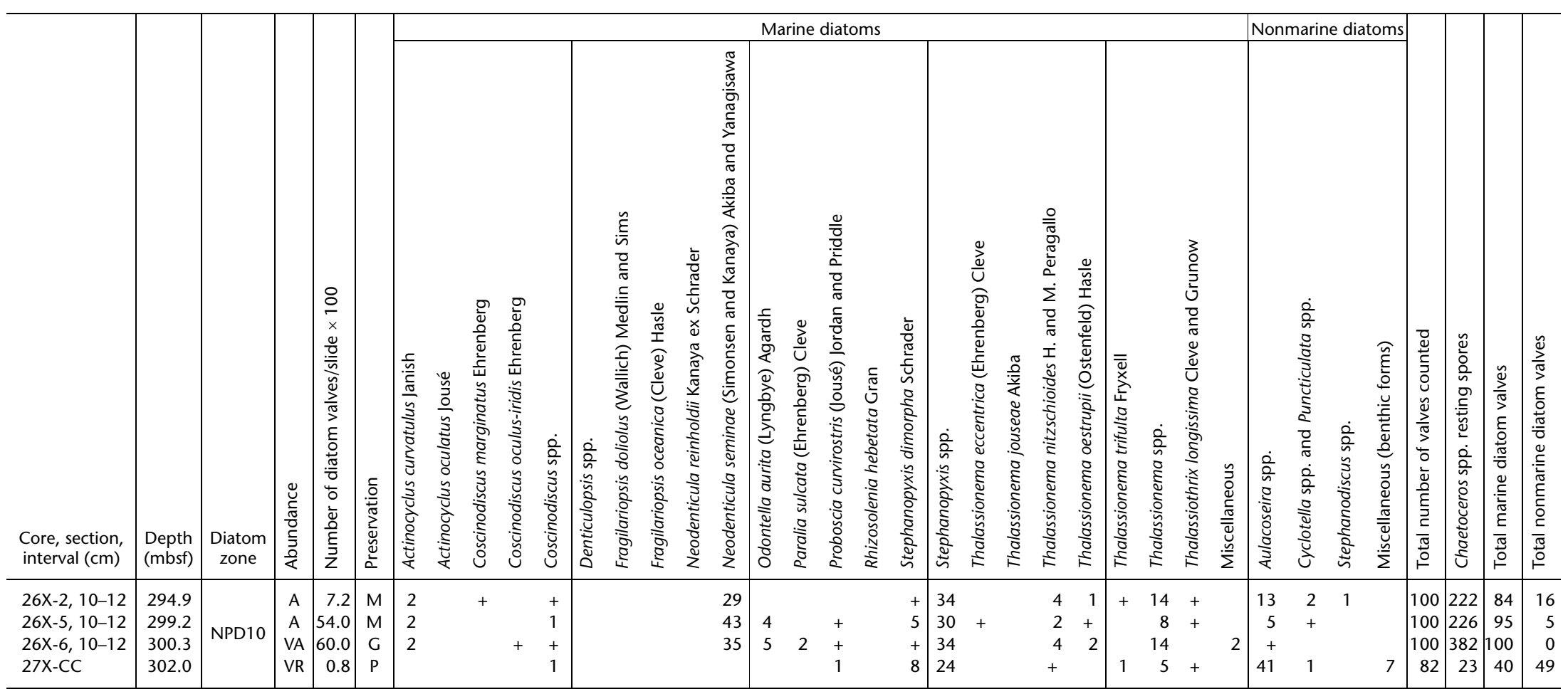

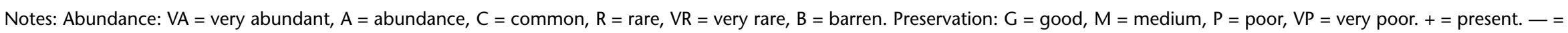
not applicable. 
Table T2. Foraminifers, Holes U1328B and U1328C. This table available in an oversized format.

Table T3. Depth and age data, Sites U1325-U1329. (See table notes.)

\begin{tabular}{|c|c|c|c|c|c|c|c|}
\hline \multirow[b]{2}{*}{ Event } & \multirow[b]{2}{*}{ Depth (mbsf) } & \multicolumn{2}{|c|}{ Depth (mbsf) } & \multicolumn{2}{|c|}{ Core, section, interval $(\mathrm{cm})$} & \multirow[b]{2}{*}{ Age (Ma) } & \multirow{2}{*}{$\begin{array}{c}\text { Sedimentary } \\
\text { rate }(\mathrm{m} / \mathrm{m} . \mathrm{y} .) \\
\text { until next event }\end{array}$} \\
\hline & & Top & Bottom & Top & Bottom & & \\
\hline & & & & U1325B- & U1325B- & & \\
\hline- & 0 & - & & & & 0.0 & 408.3 \\
\hline LO Proboscia curvirostris & 122.50 & 115.47 & 129.49 & $15 X-C C$ & $16 \mathrm{X}-\mathrm{CC}$ & 0.3 & 104.4 or higher \\
\hline B NPD11 & 195.60 & 192.03 & 199.08 & $1 \mathrm{X}-\mathrm{CC}$ & $2 \mathrm{X}-\mathrm{CC}$ & 1.0 or younger & - \\
\hline- & 199.00-299.00 & - & & $15 X-C C$ & $2 \mathrm{X}-\mathrm{CC}$ & Unknown & - \\
\hline & & & & U1326C- & U1326C- & & \\
\hline- & 0 & - & & & & 0.0 & \\
\hline B NPD12 & 25.20 & 22.13 & 28.27 & $3 \mathrm{H}-\mathrm{CC}$ & $4 \mathrm{H}-\mathrm{CC}$ & 0.3 or younger & 468.6 or lower \\
\hline LO Proboscia curvirostris & 140.60 & 141.65 & 150.50 & $\begin{array}{l}\text { U1326D- } \\
7 X-C C\end{array}$ & $\begin{array}{l}\text { U1326CD- } \\
8 \mathrm{X}-\mathrm{CC}\end{array}$ & 0.3 or older & 174.2 or higher \\
\hline B NPD11 & 262.60 & 254.44 & 270.69 & $19 \mathrm{X}-\mathrm{CC}$ & $20 \mathrm{X}-\mathrm{CC}$ & 1.0 or younger & - \\
\hline- & 270.70 & & & $20 \mathrm{X}-\mathrm{CC}$ & & Unknown & - \\
\hline & & & & U1327C- & U1327C- & & \\
\hline- & 0 & - & & & & 0.0 & 202.6 \\
\hline LO Proboscia curvirostris & 60.80 & 55.98 & 65.64 & $7 \mathrm{H}-\mathrm{CC}$ & $8 \mathrm{H}-\mathrm{CC}$ & 0.3 & 160.1 \\
\hline LO Actinocyclus oculatus & 172.90 & 167.20 & 178.68 & $20 \mathrm{X}-\mathrm{CC}$ & $21 X-C C$ & 1.0 & 207.8 or higher \\
\hline FO Proboscia curvirostris & 297.60 & 295.26 & 299.88 & $34 \mathrm{X}-\mathrm{CC}$ & $35 \mathrm{X}-\mathrm{CC}$ & 1.6 or younger & - \\
\hline- & 299.90 & & & $35 X-C C$ & & Unknown & - \\
\hline & & & & U1328C- & U1328C- & & \\
\hline- & 0 & - & & & & 0.0 & 306.0 \\
\hline LO Proboscia curvirostris & 91.80 & 89.40 & 94.10 & $4 \mathrm{X}-\mathrm{CC}$ & $6 \mathrm{H}-1,10-12$ & 0.3 & 118.1 \\
\hline LO Actinocyclus oculatus & 174.50 & 174.20 & 174.70 & $14 X-5,10-13$ & $14 \mathrm{X}-\mathrm{CC}$ & 1.0 & 212.5 or higher \\
\hline FO Proboscia curvirostris & 302.00 & 302.00 & & $27 X-C C$ & & 1.6 or younger & - \\
\hline & & & & U1329C- & U1329C- & & \\
\hline- & 0 & - & & & & 0.0 & 108.0 \\
\hline LO Proboscia curvirostris & 32.40 & 37.18 & & $3 \mathrm{H}-\mathrm{CC}$ & $4 \mathrm{H}-\mathrm{CC}$ & 0.3 & 97.3 \\
\hline LO Actinocyclus oculatus & 100.50 & 105.32 & & $11 \mathrm{H}-\mathrm{CC}$ & $12 \mathrm{H}-\mathrm{CC}$ & 1.0 & 58.9 or higher \\
\hline FO Proboscia curvirostris & 135.80 & 135.70 & 135.98 & & & 1.6 or younger & Hiatus \\
\hline T NPD7A & 135.80 & 135.70 & 135.98 & & & 6.4 or older & 22.8 or higher \\
\hline LO Thalassionema schraderi & 163.20 & 161.20 & 165.20 & & & 7.6 & 16.4 or higher \\
\hline B NPD6B & 178.00 & 176.98 & 179.00 & & & 8.5 or younger & - \\
\hline - & $179.00-186.40$ & - & & $22 X-1$ & $22 X-6$ & Unknown & - \\
\hline
\end{tabular}

Notes: $\mathrm{FO}=$ first occurrence, $\mathrm{LO}=$ last occurrence, $\mathrm{B}=$ base, $\mathrm{T}=$ top. $-=$ not defined or calculated. 
Plate P1. Light microscope images of marine diatoms, Holes U1325B, U1327C, U1328C, and U1329C. 1, 2. Thalassionema schraderi Akiba (Sample 311-U1329C-20X-CC), (1) valve view of valve and (2) girdle view of frustule. 3-6. Neodenticula seminae (Simonsen and Kanaya) Akiba and Yanagisawa; $(3,6)$ Sample 311-U1329C-5H-CC; $(4,5)$ Sample 311-U1325B-18X-CC; (4) girdle view of frustule. 7. Thalassionema nitzschioides (Grunow) H. and M. Peragallo (Sample 311-U329C-20X-1, 10-20 cm). 8-15. Chaetoceros resting spores and allied genera; (8-10, 12, 14-15) Sample 311-U1327C-20X-CC; $(11,13)$ Sample 311U1328C-11X-2, 7-9 cm.
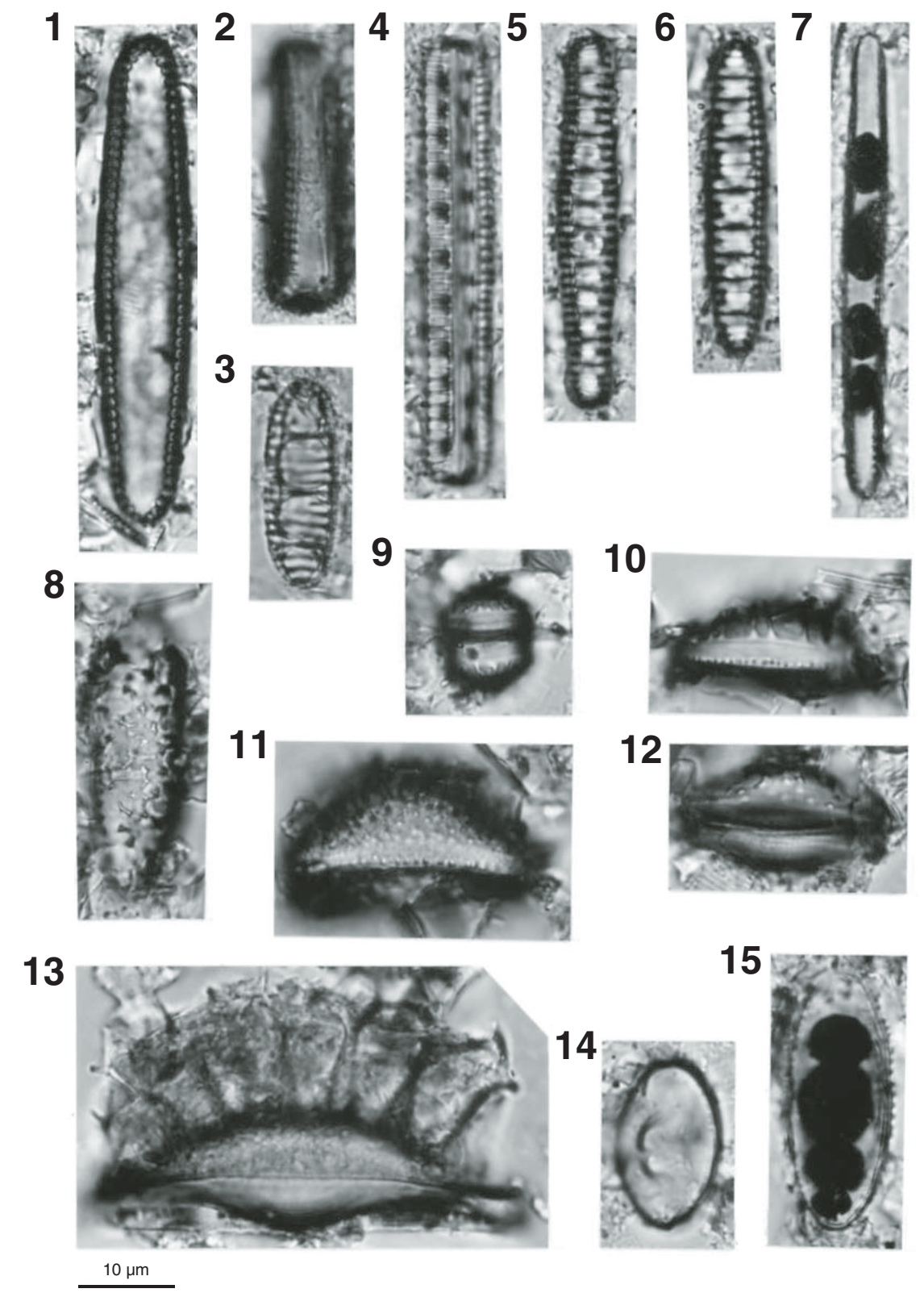
Plate P2. Light microscope images of freshwater diatoms, Holes U1328B, I1328C, and U1329C. 1, 2. Stephanodiscus cf. niagarae Ehrenberg (Sample 311-U1328C-15X-1, 10-12 cm), focused on (1) central area and (2) margin. 3. Stephanodiscus Ehrenberg sp. (Sample 311-U1328C-12X-5, 10-12 cm). 4, 5. Puncticulata Håkansson sp. (Sample 311-U1328C-15X-1, 10-12 cm), focused on margin (4) and (5) central area. 6. Puncticulata radiosa (Grunow) Håkansson (Sample 311-U1328B-9H-6, 11-12 cm). 7. Cyclotella (Kützing) Brébisson spp. (Sample 311-U1328C-12X-5, 10-12 cm). 8. Discostella stelligera (Cleve and Grunow) Houk and Klee (Sample 311-U1328C-15X-1, 10-12 cm). 9. Cyclotella (Kützing) Brébisson sp. (Sample 311-U1328C-20X-2, 10-12 cm). 10. Cyclotella ocellata Pantocsek (Sample 311-U1328C-15X-1, 10-12 cm). 11. Cyclotella (Kützing) Brébisson sp. (Sample 311-U1328C-15X-1, 10-12 cm). 12. Cyclotella polymorpha B. Meyer and Håkansson (Sample 311-U1328C-15X-1, 10-12 cm). 13. Cyclotella tripartita Håkansson (Sample 311-U1328C-12X-4, 10-12 cm). 14-24. Aulacoseira Thwaites sp.; $(14,23)$ Sample 311-U1328B-9H-6, 11-12 cm; $(15,17,20)$ Sample 311U1328C-15X-1, 10-12 cm; (16, 19) Sample 311-U1328C-20X-2, 10-12 cm; (18) Sample 311-U1329C-22X$3,10-12 \mathrm{~cm} ;(21,22,24)$ Sample 311-U1328B-9H-5, 11-12 cm, focused on (21) valve face and (22) sulcus. 25, 26. Aulacoseira solida (Eulenstein) Krammer (Sample 311-U1329C-22X-3, 10-12 cm).

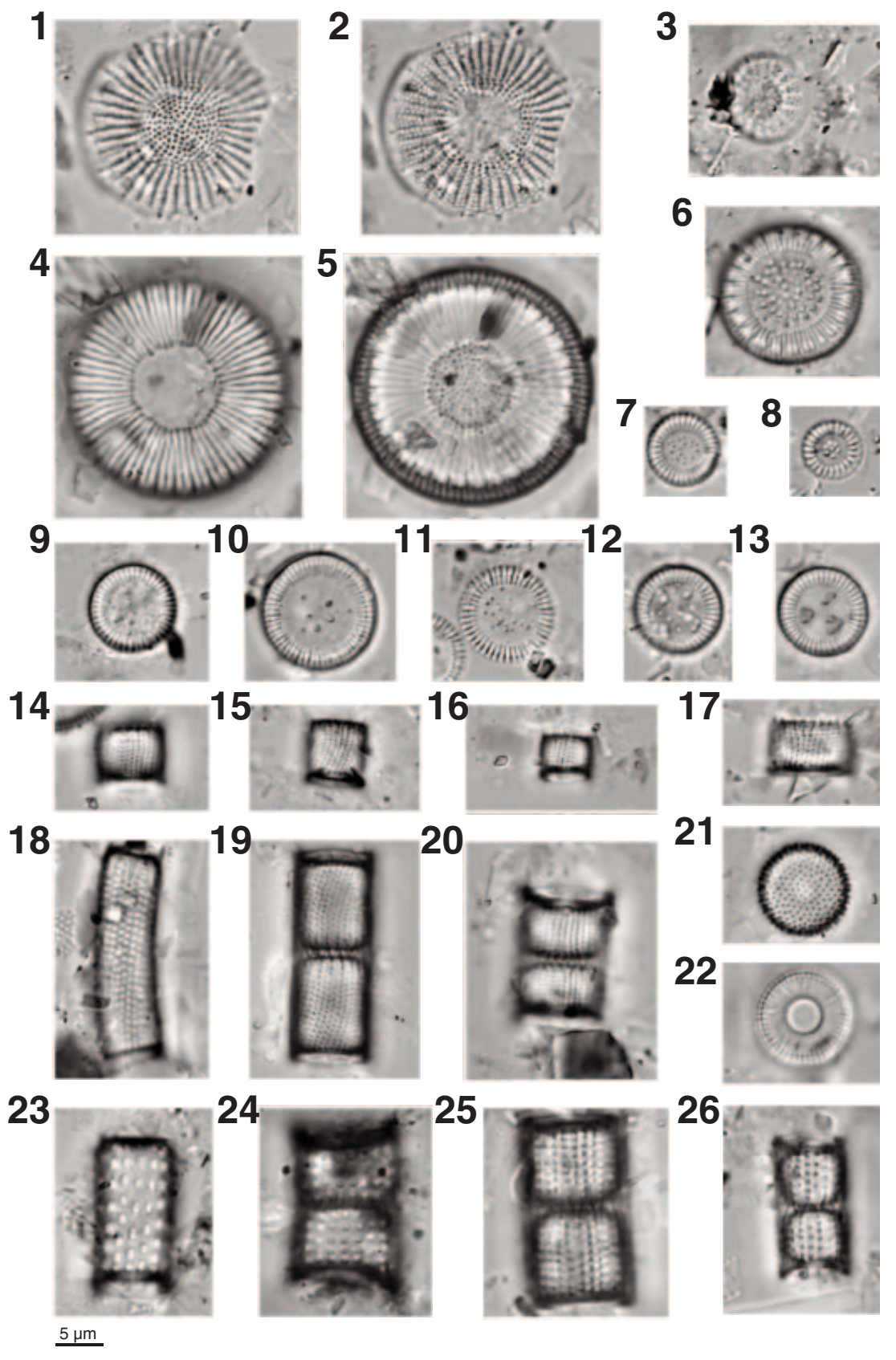


Plate P3. Scanning electron microscope images of freshwater diatoms, Holes U1328C and U1329C. 1, 3, 5. Puncticulata Håkansson spp. (Sample 311-U1328C-15X-1, 10-12 cm). 2, 4. Cyclotella (Kützing) Brébisson spp. (Sample 311-U1328C-15X-1, 10-12 cm). 6. Cyclotella ocellata Pantocsek? (Sample 311-U1328C-15X-1, 10-12 cm). 7. Aulacoseira Thwaites sp. (Sample 311-U1328C-20X-2, 10-12 cm). 8. Cyclotella ocellata Pantocsek (Sample 311-U1328C-15X-1, 10-12 cm).
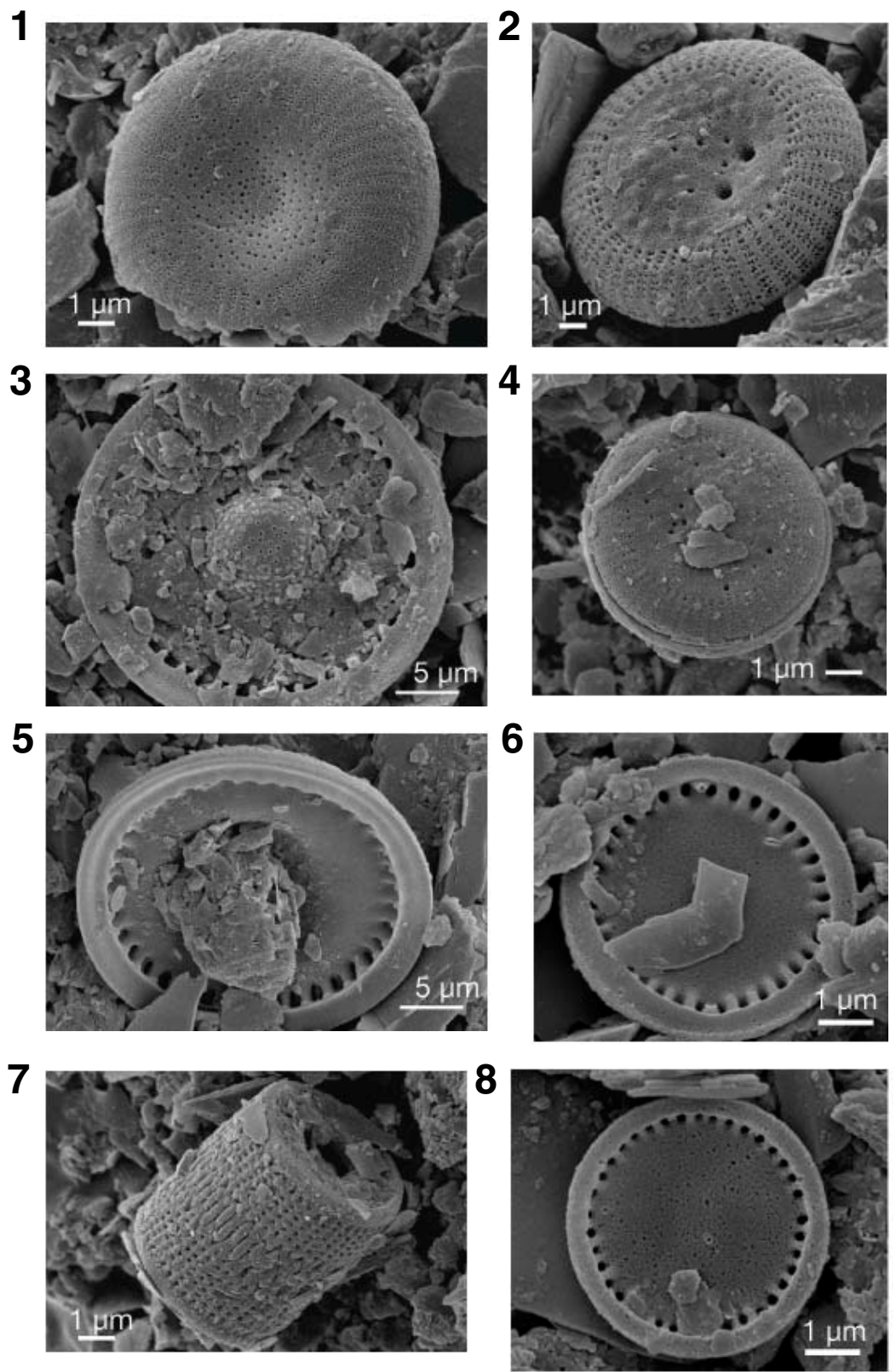
Plate P4. Light microscope images of marine diatoms, Holes U1325B, U1327C, and U1329C. 1. Thalassiosira antiqua (Grunow) Cleve-Euler (Sample 311-U1329C-20X-1, 10-20 cm). 2. Thalassiosira jouseae Akiba (Sample 311-U1329C-5H-CC). 3. T. jouseae Akiba (Sample 311-U1329C-16H-CC). 4. Stephanopyxis dimorpha Schrader (Sample 311-U1329C-16H-CC). 5. Actinocyclus oculatus Jousé (Sample 311-U1327C-32X-CC). 6. Proboscia curvirostris (Jousé) Jordan and Priddle (Sample 311-U1325B-18X-CC). 7. Actinocyclus curvatulus Janisch (Sample 311U1329C-5H-CC). 8. Thalassiosira oestrupii (Ostenfeld) Proshkina (Sample 311-U1325B-18X-CC). Note many small grains of probable organic matter observed inside the diatom, which are also seen in other specimens (Pl. P1, figs. 7, 15).

1

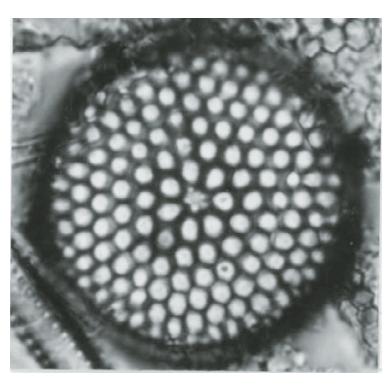

4

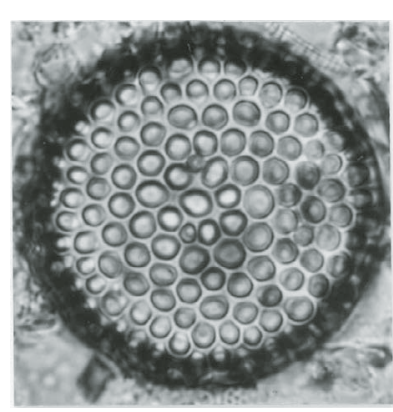

2

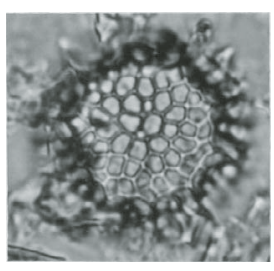

3

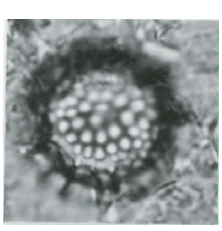

6

5

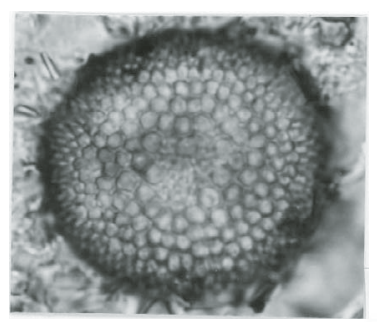

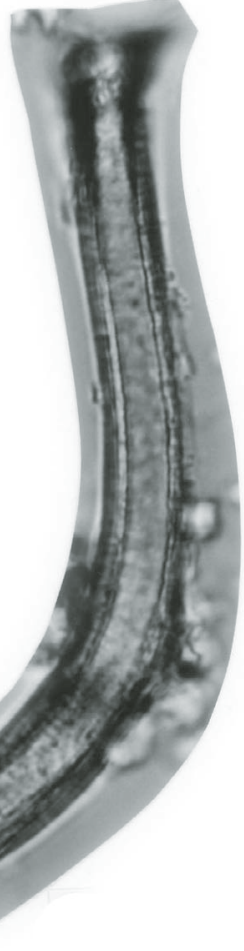

8

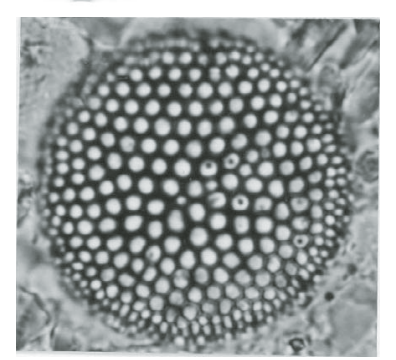

